\title{
Anti-vibrio effects of the precious Tibetan pill, Rinchen Drangjor Rilnag Chenmo (RDRC)
}

\author{
Sonam Dhargyal, Indhu Philip, Soma Biswas \& Suma Sarojini* \\ Department of Life Sciences, CHRIST (Deemed to be University), Bangalore 29, India \\ *Email: suma@christuniversity.in
}

ARTICLE HISTORY

Received: 23 April 2021

Accepted: 13 June 2021

Available online: 01 July 2021

\section{KEYWORDS}

Rinchen Drangjor Rilnag Chenmo

Antibacterial activity

Antifungal effect

Minimum Inhibitory Concentration

Minimum Bactericidal

Concentration (MBC)

\begin{abstract}
Tibetan precious pills are an integral part of TTM (Traditional Tibetan Medicine). Among them, Rinchen Drangjor Rilnag Chenmo (RDRC) has been named "King of Precious Pills" due to its efficacy in treating a multitude of human disorders. RDRC has a complex formulation with about 140 ingredients, mostly from medicinal plants and a few precious stones and metals. Not many studies have been done on the experimental validation of antimicrobial properties of this important pill. The current study investigated the antimicrobial activity of the extracts of RDRC. Both aqueous and chloroform extracts were evaluated for their antibacterial potential against a total of seven different bacterial species, which are pathogenic, including three species of Vibrio, viz. V. vulnificus, V. parahaemolyticus and V. harveyi using the well-diffusion method and also by assessing MIC and MBC values. Its antifungal potential was also studied against two fungal strains Aspergillus niger and Talaromyces islandicus. It was found that the chloroform extract of RDRC exerted a positive antibacterial effect on all the Vibrio species tested, and the least MIC of $3.33 \mathrm{mg} / \mathrm{ml}$ was observed for $V$. parahaemolyticus. This is the first study of its kind on the anti-Vibrio effect of the Tibetan precious pill, Rinchen Drangjor Rilnag Chenmo.
\end{abstract}

\section{Introduction}

Traditional Tibetan Medicine (TTM), also known as Sowa-Rigpa in Tibetan (literally translates to "Science of Healing") is one of the oldest traditional medical systems dating back to the 4th century (1) and world's first integrative medicine (2) with its influence from Chinese, Greco-Arab, Himalayan and Indian medical systems in the 8th century (3). Since then, this holistic and comprehensive medical system has developed as the main medical system in Tibet. Currently, TTM has gained its popularity in India, Nepal, Bhutan, Mongolia, China and western countries. In September 2010, Indian Government officially recognized the Sowa-Rigpa as an integral part of its national healthcare system, making it the fourth country after China, Bhutan and Mongolia to recognize it (4). One of the most important precious pills in Traditional Tibetan Medicine is Rinchen Drangjor Rilnag Chenmo (RDRC). It is considered the "King of Precious Pills" among the eight precious pills (6). It has been proposed to cure a multitude of diseases and also has rejuvenating effects on the healthy. It is believed to enhance complexion and clear sense organs. It is also a rejuvenator, acts as an aphrodisiac, strengthens nerves, blood vessels and bones (6). RDRC is considered to have prophylactic effects too (6). It is given for a range of diseases from simple to complex and diseases caused by environmental pollution (5). It is also used as a tonic and worn as a protective amulet. RDRC is found to have about 140 ingredients, including detoxified Mercury or Tsothel. It also contains powder from precious stones and metals such as gold, silver, copper, iron, sapphire, diamond, emerald, turquoise etc (6). Some of the important medicinal plants used to prepare these pills are Crocus sativus Linn., Myristica fragrans Houtt., Phytolacca esculenta van Houtte., Terminalia bellerica Roxb. and Terminalia chebula Retz. (6). The preparation method of RDRC has been done sacredly by only a few Tibetan masters and is created on the basis of the practical instructions of the great ancient Masters of Tibetan medicine and enriched with their spiritual blessings. RDRC has been predicted to cure diseases of the gastrointestinal tract, infectious fevers, colic in the small intestine and even cancer (6). It has also been found to eliminate grey hair, wrinkles and is also known to strengthen bones. In China, RDRC has made it to the UNESCO inspired 'Intangible cultural heritage list' in $2006(7,8)$. Since its recognition in India from 2010, no work has been done to scientifically validate its claim that is to treat infectious diseases, there is not one single scientific paper on this pill to back up its claim. Therefore, we decided to test the efficacy of both the chloroform and aqueous extracts of RDRC

(c) Dhargyal et al (2021). This is an open-access article distributed under the terms of the Creative Commons Attribution License, which permits unrestricted use, distribution and reproduction in any medium, provided the original author and source are credited (https://creativecommons.org/licenses/by/4.0/). 
against two Gram-positive and five Gram-negative bacteria and two fungal species.

\section{Materials and Methods}

\section{Sample collection}

Rinchen Drangjor Rilnag Chenmo (RDRC) pills were bought from the Men-Tsee-Khang branch clinic in Koramangala, Bangalore, after permission from the Director of Men-Tsee-Khang (Tibetan Medical and Astro-science Institute), Himachal Pradesh, India.

\section{Microbial strains}

Staphylococcus aureus (ATCC 29213) and Bacillus velezensis (MW219533.1) were used as the bacterial indicator strains for Gram-positive bacteria. Escherichia coli (ATCC MG1655), Pseudomonas aeruginosa (ATCC 27853), Vibrio harveyi, Vibrio parahaemolyticus and Vibrio vulnificus were used as the bacterial indicator strains for Gram-negative bacteria for antibacterial studies. Aspergillus niger (MT123512.1) and Talaromyces islandicus (MT123786.1) were used for checking antifungal activity. Some cultures have been maintained in the University and few were a gift from IISc, Department of Cell and Molecular Biology. The culture collection details are given in brackets.

\section{Extraction process}

$10 \mathrm{gm}$ of pulverized pills were packed uniformly inside a thimble, and a sample was extracted using $120 \mathrm{ml}$ chloroform in a distillation flask at the boiling point of chloroform $\left(62{ }^{\circ} \mathrm{C}\right)$. During the process, condensated fresh chloroform gradually fills the thimble holder, and once it reaches the overflow level, the solute is aspirated by siphoning from the thimble holder back to the distillation flask with extracted analytes (9). This process was repeated for $7 \mathrm{hrs}$ until the extractant became colourless. Because of the large amount of solvent used, the concentration step was essential after extraction using Rotary evaporator (Royal Scientific 137). The same RDRC sample was dried in a hot air oven and sequentially extracted using distilled water for $18 \mathrm{hrs}$ and concentrated using rotavapor. The dried extracts were stored at $4{ }^{\circ} \mathrm{C}$ for further uses.

\section{Phytochemical analysis}

The RDRC extracts were subjected for phytochemical analysis by employing standard methods such as alkaline reagent test for flavonoids, Benedict's reagent test for carbohydrates, ferric chloride test for phenols, steroids, tannins, foam test for saponins, Mayer's test for alkaloids and Salkowski's test for glycosides (10).

\section{Antibacterial assay}

The aqueous and chloroform extracts of RDRC were checked for their antibacterial activity using the in vitro agar well-diffusion method (11). Sterile cotton swabs were used to inoculate the cultured microbial strains on Mueller-Hinton (MH) agar (HiMedia Laboratories Pvt. Ltd.) plates for antibacterial study. A sterile well-borer of $5.0 \mathrm{~mm}$ diameter was used to make wells, and different concentrations of aqueous and chloroform extracts were loaded $(0.25,0.50,0.75$, $1.0,1.25$ and $1.5 \mathrm{mg} / \mathrm{ml}) .10 \mathrm{mg} / \mathrm{ml}$ of aqueous extract was prepared in sterile distilled water, whereas 10 $\mathrm{mg} / \mathrm{ml}$ of chloroform extract was prepared in Dimethyl Sulfoxide (Qualikems Fine Chem Pvt. Ltd.). Ampicillin (HiMedia Laboratories Pvt. Ltd.) was used as a positive control for an antibacterial study. Since the chloroform extract was dissolved in Dimethyl Sulfoxide (DMSO), DMSO was treated as a negative control. The bacterial plates were incubated for 24 hrs at $37{ }^{\circ} \mathrm{C}$. Its antibacterial activities were measured using a zone of inhibition (ZOI) in millimetre (mm). It was done in triplicates under aseptic conditions.

\section{Determination of MIC and MBC}

Minimum Inhibitory Concentration (MIC) of RDRC extract was assessed by tube dilution method. Serial two-fold dilutions of the extract were made starting from $20 \mathrm{mg} / \mathrm{ml}$ Mueller-Hinton Broth to assess bacterial growth. The concentrations used for the MIC study included 20, 10, 5, 2.5, 1.25, 0.625 and $0.3125 \mathrm{mg} / \mathrm{ml}$. Overnight cultures of bacteria were inoculated in $\mathrm{MH}$ broth with different RDRC extract concentrations, incubated at $37{ }^{\circ} \mathrm{C}$ overnight in a shaker incubator (Orbital Shaker Incubator (Remi CIS-24BL), and turbidity measurements (Colorimeter, ELICO, CL137) were taken the next day at $\mathrm{OD}_{600}$. MIC was determined as the lowest concentration that inhibited the visible growth of microorganisms. In order to assess the Minimum Bactericidal Concentration (MBC), aliquots of $50 \mu \mathrm{l}$ from all the tubes which showed no visible bacterial growth were seeded on $\mathrm{MH}$ agar plates and incubated for $24 \mathrm{hr}$ at $37^{\circ} \mathrm{C}$. The number of colonies counted the next day. When $99.9 \%$ of the bacterial population is killed at the least concentration of an antimicrobial agent, it is fixed as its MBC. This was done by observing pre- and post-incubated agar plates for the presence or absence of bacterial colonies. Experiments were replicated thrice $(n=3)$ and represented as mean $\pm S D$.

\section{Anti fungal assay}

Sterile cotton swabs were used to inoculate the cultured fungal strains on Potato Dextrose Agar (HiMedia Laboratories Pvt. Ltd.) plates for antifungal study. A sterile well-borer of $5 \mathrm{~mm}$ diameter was used to make wells, and different concentrations of aqueous and chloroform extracts were loaded $(0.25$, $0.50,0.75,1.0,1.25$ and $1.5 \mathrm{mg} / \mathrm{ml}) .10 \mathrm{mg} / \mathrm{ml}$ of aqueous extract was prepared in sterile distilled water, whereas $10 \mathrm{mg} / \mathrm{ml}$ of chloroform extract was prepared in DMSO. Sporanox (Johnson \& Johnson Pvt. Ltd.) was used as a positive control for antifungal study (12). DMSO was used as a negative control. The fungal plates were kept at room temperature for 5-7 days. Its antifungal activities were assessed by measuring the zone of inhibition (ZOI) in millimetre $(\mathrm{mm})$. It was also done in triplicates under aseptic conditions.

\section{Statistical analysis}

All the values were expressed as mean \pm S.D of three parallel measurements. Statistical analyses for the antimicrobial activities were performed using the SPSS software package. The mean values were 
analyzed by one-way ANOVA. To determine the statistical significance of antimicrobial activity, Duncan's Multiple Range Test (DMRT) was used. pvalues $<0.05$ were regarded as significant.

\section{Results and Discussion}

Natural medicines derived from parts of plants, animals and minerals obtained from Earth have been found to play important roles in fighting various diseases. With its long history of more than 2000 years, Traditional Tibetan Medicine (TTM) has been well recognized in Tibet and other parts of the world. TTM has been considered to play a significant role in the prevention and treatment of various diseases, including cancer (5). In the current study, the extract of the pill RDRC was prepared using chloroform and water. Water was used for extraction of the polar and semi-polar constituents. However, for lipophilic compounds, lipophilic solvents such as chloroform were used for extraction. The phytochemical analysis of both extracts as shown in Table 1 indicated the

Table 1. Phytochemical screening test of chloroform and aqueous RDRC extracts

\begin{tabular}{lcc}
\hline $\begin{array}{c}\text { Phytochemical } \\
\text { compounds }\end{array}$ & $\begin{array}{c}\text { Chloroform extract } \\
\text { of RDRC }\end{array}$ & $\begin{array}{c}\text { Aqueous extract of } \\
\text { RDRC }\end{array}$ \\
\hline Alkaloid & + & + \\
\hline Carbohydrate & + & + \\
\hline Flavonoid & + & + \\
\hline Glycoside & + & + \\
\hline Phenol & + & + \\
\hline Saponin & + & + \\
\hline Steroid & + & + \\
\hline Tannin & + & +
\end{tabular}

$(+)$ represents the presence of the mentioned compounds and (-) represents the absence of the compounds.

presence of alkaloids, carbohydrates, flavonoids, glycosides, phenols, saponins, steroids and tannins. These RDRC extracts were screened in vitro for antibacterial activity by the agar well diffusion method (Table 2 and 3). Both the extracts did not show any activity against tested Gram-positive bacteria, as shown in Table 3 . However, chloroform extract exhibited considerable activity (Fig. 1) against three Vibrio species: V. harveyi at $1,1.25$ and $1.5 \mathrm{mg} /$ $\mathrm{ml}$ showed zone of inhibition (ZOI) of 7.0 $\pm 0.0,9.0 \pm$ 1.0 and $10.0 \pm 0.0 \mathrm{~mm}$ respectively; $V$. vulnificus at $0.75,1,1.25$ and $1.5 \mathrm{mg} / \mathrm{ml}$ exhibited ZOI of $5.6 \pm 0.5$, $7.6 \pm 0.5,9.3 \pm 0.5$ and $10 \pm 1.0 \mathrm{~mm} ; \quad V$. parahaemolyticus was more sensitive with its ZOI noticeable even at $0.25 \mathrm{mg} / \mathrm{ml}$ as displayed in Table 2 . Since the chloroform extract was dissolved using DMSO and diluted using distilled water, DMSO (Solvent) inhibition was also checked, and it exhibited no inhibition. RDRC extracts were assayed for antifungal activity against two fungal strains, but both the extracts were inactive and exhibited no fungicidal activities (Table 4).

MIC values were assessed for the three Vibrio species for which RDRC extract showed antibacterial activity as evidenced by the zone of inhibition. The least MIC value $(3.33 \pm 1.44 \mathrm{mg} / \mathrm{ml})$ was observed for $V$. parahaemolyticus and the highest $(5.00 \pm 0 \mathrm{mg} / \mathrm{ml})$ for $V$. harveyi. MBC values were calculated for $V$. parahaemolyticus, V. vulnificus and $V$. harveyi (Table $5)$, in which $V$. parahaemolyticus had the least MBC of $8.33 \pm 2.88 \mathrm{mg} / \mathrm{ml}$, which shows that the chloroform extract of RDRC was the most efficacious against $V$. parahaemolyticus.

Many Vibrio species have been associated with aquatic ecosystems. $V$, parahaemolyticus is commonly found in rivers and estuaries. Food poisoning caused by $V$. parahaemolyticus usually occurs in summer. It is mostly manifested in people consuming seafood like crab, shrimp, shellfish, lobster, fish and oysters (13-14). V. parahaemolyticus is a human pathogen and can cause acute gastroenteritis due to contaminated raw or undercooked seafood. It also can cause infections in open wounds exposed to seawater. This Gram-negative comma-shaped bacterium is the leading cause of seafood-related gastroenteritis (15). V. parahaemolyticus is reported to cause around 35000 cases of gastroenteritis per year in the USA alone (16). Certain serogroups of bacteria causing various gastroenteritis diseases turn out to be highly virulent and can even cause pandemics. One such is the 03:K6 serogroup of $V$. parahaemolyticus, which emerged in India in 1996 and has since spread to other Asian countries (17).

Some strains of $V$. parahaemolyticus have been found to be antibiotic-resistant. Hence, the use of synthetic antibiotics should be done with caution as these inhibitors based on chemical molecules often lead to bacterial drug resistance or leave residues in the environment, which can pose a threat to animal and human health (18). In this scenario, the importance of natural products to combat pathogens can be looked at. Most of the ingredients of RDRC are obtained from nature. The current study showed significant anti-Vibrio activity against $V$. parahaemolyticus as evidenced by the zone of inhibition of about $13 \mathrm{~mm}$. In another study, natural products like cumin have been reported to have antibacterial effects on $V$. parahaemolyticus (19).

Vibrio vulnificus causes both foodborne and wound infections and is notorious for being responsible for the highest death rate caused by any foodborne disease agent in the USA (20). This pathogen is highly invasive and can cause septicemia in persons with reduced immunity; and is responsible for $95 \%$ of all seafood-related deaths in the USA, with a mortality rate of $60 \%$ (21). But not all strains of $V$. vulnificus have been found to be highly virulent (22). Most of the deaths occur within $72 \mathrm{hrs}$ if proper treatment is not given. Generally, a combination of tetracyclines and third-generation cephalosporins are given as treatment. There has been increasing evidence of $V$. vulnificus becoming resistant to antibiotics and hence, it becomes necessary to explore newer anti-Vibrio compounds, especially of natural origin. A previous report has depicted the anti-Vibrio activity of the plant Ocimum gratissimum Linn. (23). Present study has yielded a positive result for antibacterial activity of RDRC extract against $V$. vulnificus, as the zone of inhibition was found to be about $10 \mathrm{~mm}$. Hence, this Tibetan Precious pill, RDRC can be thought of as a part of the 
Table 2. Antibacterial activity of RDRC extracts in comparison with standard antibiotic ampicillin against Gram-negative bacterial strains

\begin{tabular}{|c|c|c|c|c|c|c|}
\hline \multirow[b]{2}{*}{ Compound } & \multirow[b]{2}{*}{ Conc. (mg/ml) } & \multicolumn{5}{|c|}{ Zone of Inhibition (mm) } \\
\hline & & Escherichia coli & $\begin{array}{c}\text { Pseudomonas } \\
\text { aeruginosa }\end{array}$ & Vibrio vulnificus & Vibrio harveyi & $\begin{array}{c}\text { Vibrio } \\
\text { parahaemolyticus }\end{array}$ \\
\hline \multirow{6}{*}{ Chloroform extract } & 0.25 & 0 & 0 & 0 & 0 & $0.6 \pm 0.0$ \\
\hline & 0.50 & 0 & 0 & 0 & 0 & $0.7 \pm 0.0$ \\
\hline & 0.75 & 0 & 0 & $5.6 \pm 0.5$ & 0 & $10.0 \pm 1.0$ \\
\hline & 1.00 & 0 & 0 & $7.6 \pm 0.5$ & $7.0 \pm 0.0$ & $11.3 \pm 0.5$ \\
\hline & 1.25 & 0 & 0 & $9.3 \pm 0.5$ & $9.0 \pm 1.0$ & $12.00 \pm 0$ \\
\hline & 1.50 & 0 & 0 & $10 \pm 1.0$ & $10.0 \pm 0.0$ & $13 \pm 2.00$ \\
\hline \multirow{6}{*}{$\begin{array}{c}\text { Aqueous } \\
\text { extract }\end{array}$} & 0.25 & 0 & 0 & 0 & 0 & 0 \\
\hline & 0.50 & 0 & 0 & 0 & 0 & 0 \\
\hline & 0.75 & 0 & 0 & 0 & 0 & 0 \\
\hline & 1.00 & 0 & 0 & 0 & 0 & 0 \\
\hline & 1.25 & 0 & 0 & 0 & 0 & 0 \\
\hline & 1.50 & 0 & 0 & 0 & 0 & 0 \\
\hline Ampicillin & 0.5 & 0 & $14 \pm 1.0$ & $17.6 \pm 0.5$ & $19 \pm 0.0$ & $20 \pm 2.0$ \\
\hline DMSO & & 0 & 0 & 0 & 0 & 0 \\
\hline
\end{tabular}

values are presented as mean \pm standard deviation of three independent experiments where $\mathrm{p}<0.05$

Table 3. Antibacterial activity of RDRC extracts in comparison with standard antibiotic ampicillin against Gram-positive bacterial strains

Compound

Conc. $(\mathrm{mg} / \mathrm{ml})$

\section{Zone of Inhibition (mm)}

\begin{tabular}{|c|c|c|c|}
\hline \multirow{2}{*}{ Compound } & \multirow{2}{*}{ Conc. (mg/ml) } & \\
\hline & & Bacillus velezensis & Staphylococcus aureus \\
\hline \multirow{6}{*}{ Chloroform extract } & 0.25 & 0 & 0 \\
\hline & 0.50 & 0 & 0 \\
\hline & 0.75 & 0 & 0 \\
\hline & 1.00 & 0 & 0 \\
\hline & 1.25 & 0 & 0 \\
\hline & 1.50 & 0 & 0 \\
\hline \multirow{6}{*}{ Aqueous extract } & 0.25 & 0 & 0 \\
\hline & 0.50 & 0 & 0 \\
\hline & 0.75 & 0 & 0 \\
\hline & 1.00 & 0 & 0 \\
\hline & 1.25 & 0 & 0 \\
\hline & 1.50 & 0 & 0 \\
\hline Ampicillin & 0.50 & $27.6 \pm 2.5$ & $12.6 \pm 2.0$ \\
\hline DMSO & & 0 & 0 \\
\hline
\end{tabular}

values are presented as mean \pm standard deviation of three independent experiments $(p<0.05)$

Table 4. Antifungal activity of RDRC extracts in comparison with standard antifungal sporanox against fungal strains

Compound

Chloroform extract

Aqueous extract

$$
\text { DMSO }
$$

Conc. $(\mathrm{mg} / \mathrm{ml})$

0.25
0.50
0.75

0.25

Aspergillus niger

Zone of Inhibition (mm)

\begin{tabular}{cc}
0 & 0 \\
0 & 0 \\
0 & 0 \\
0 & 0 \\
0 & 0 \\
0 & 0 \\
0 & 0 \\
0 & 0 \\
0 & 0 \\
0 & 0 \\
\hline 0 & 0 \\
\hline 0 & 0 \\
\hline $18.0 \pm 1.0$ & $7.6 \pm 0.5$ \\
\hline 0 & 0 \\
\hline
\end{tabular}

values are presented as mean \pm standard deviation of three independent experiments $(\mathrm{p}<0.05)$.

Table 5. MIC and MBC of chloroform extract of RDRC against Vibrio species

\begin{tabular}{lll}
\hline Bacterial species & MIC $\mathbf{( m g} / \mathbf{m l})$ & MBC $\mathbf{( m g} / \mathbf{m l})$ \\
\hline Vibrio vulnificus & $4.16 \pm 1.44$ & $10.0 \pm 0.00$ \\
\hline Vibrio harveyi & $5.0 \pm 0.00$ & $13.33 \pm 5.77$ \\
\hline Vibrio parahaemolyticus & $3.33 \pm 1.44$ & $8.33 \pm 2.88$ \\
\hline values are presented as mean \pm standard deviation of three independent experiments $(\mathrm{p}<0.05)$ &
\end{tabular}

anti-Vibrio therapy for manifestations of $V$. vulnificus

infections which are life-threatening.
The third bacterium we tested using RDRC extract was $V$. harveyi. It is facultatively anaerobic, 


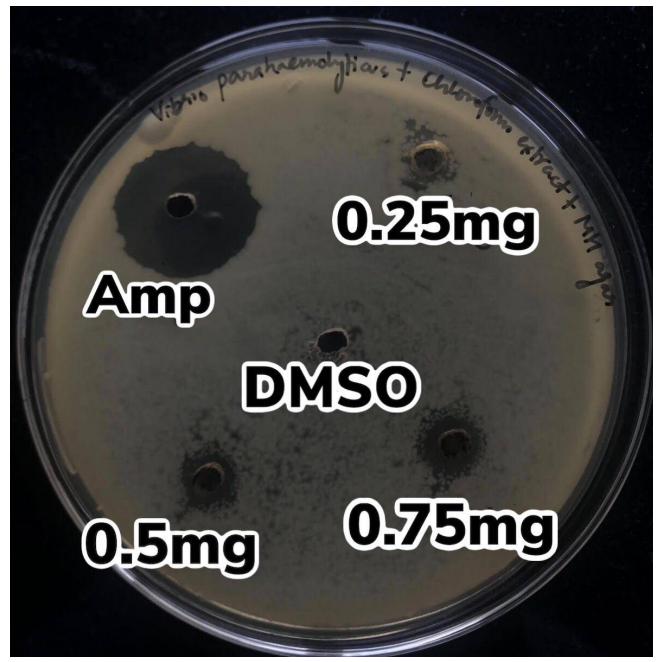

A
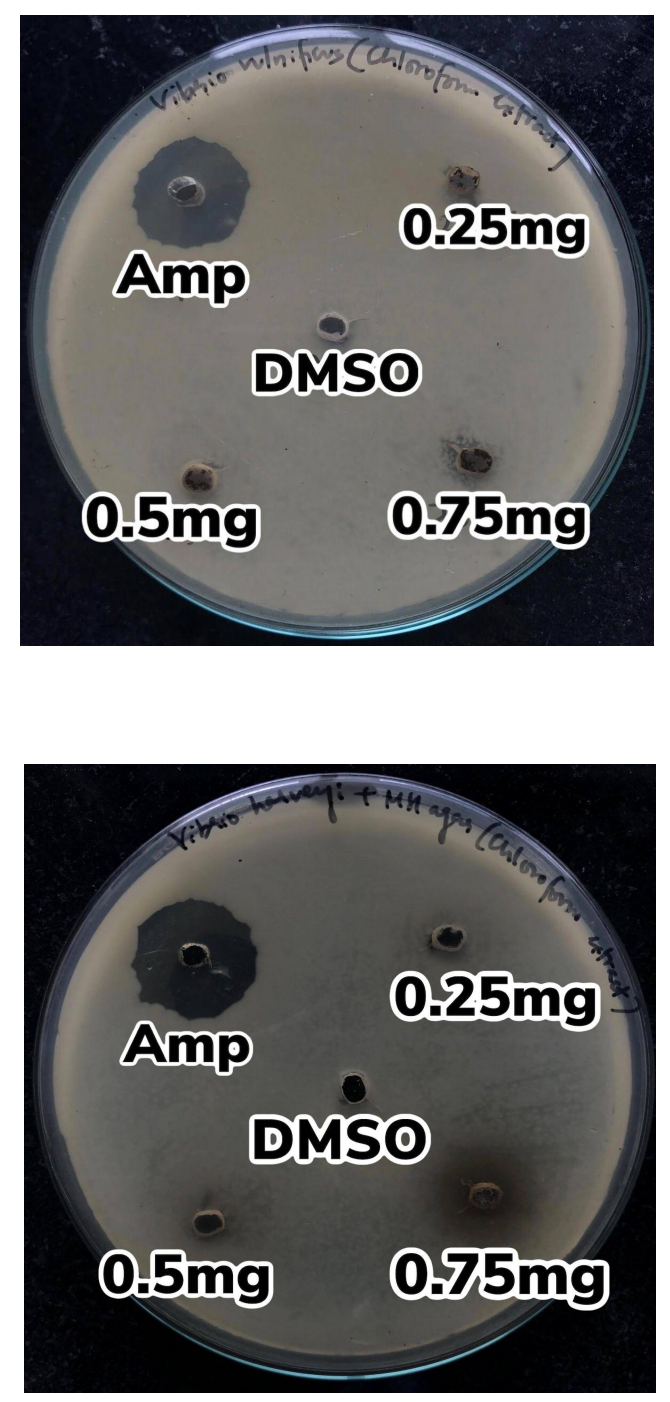
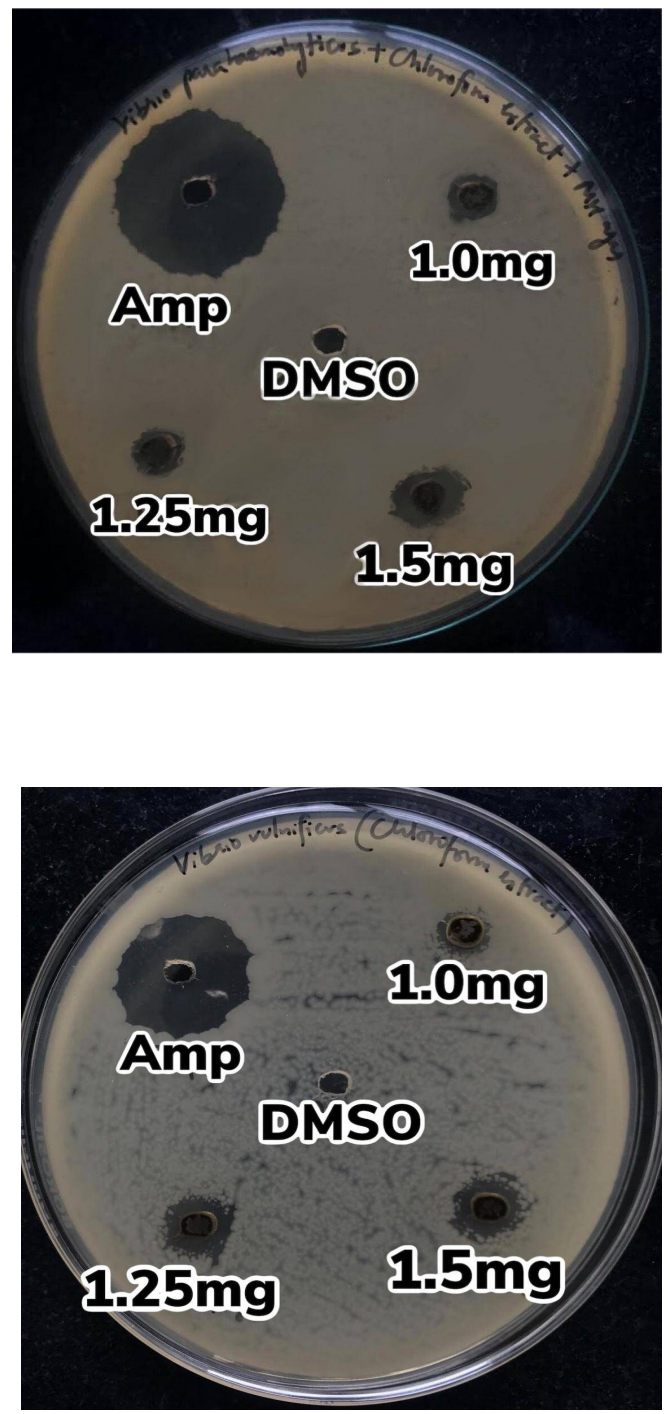

B

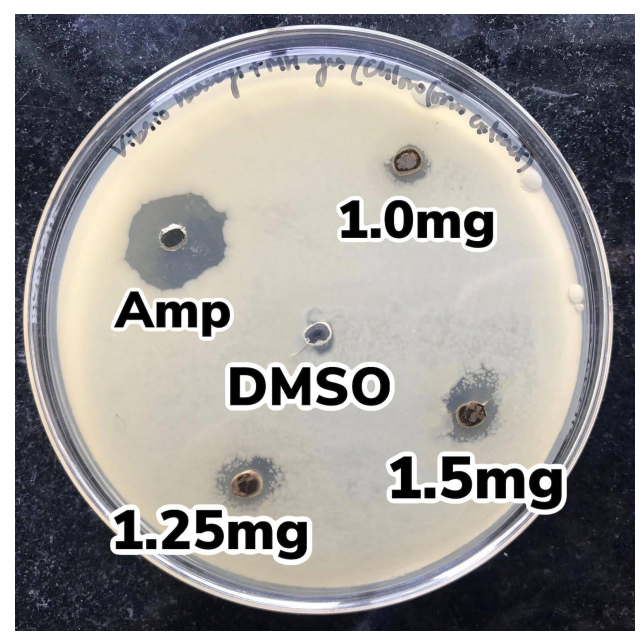

C

Fig. 1. Well diffusion method to check the antibacterial activity of Rinchen Drangjor Rilnag Chenmo (RDRC) chloroform extract at concentrations of 0.25, 0.5, 0.75, 1, 1.25 and $1.5 \mathrm{mg} / \mathrm{ml}$ against Vibrio parahaemolyticus (A) Vibrio vulnificus (B) and Vibrio harveyi (C) depicting zones of inhibition. Ampicillin was used as the standard antibiotic.

halophilic, bioluminescent and motile (24). As with other Vibrio species, $V$. harveyi is also found in tropical marine waters and also lives as a commensal in the gut microflora of marine animals. $V$. harveyi 
has been found to cause mass mortality events in benthic invertebrates in the Mediterranean Sea. This pathogen has also been pinpointed as a major threat to the survival of marine animals due to disease outbreaks owing to dramatic climate change events (25). The first report giving evidence of $V$. harveyi being a human pathogen was published in 1989, of an 11 year old girl bitten by a shark in California and subsequently getting wound infection in the year 1985 (26). The organism was confirmed to be $V$. harveyi by the Centre for Disease Control, CDC. Another four more cases were reported later, pointing to the fact that $V$. harveyi can cause human infections, though the chances are rare. There have been previous reports of Silver nanoparticles of tea leaf extract (27) and colloidal Silver nanoparticles (28) offering antibacterial activity against $V$. harveyi. Present study also has revealed potential antibacterial activity against $V$. harveyi by the chloroform extract of RDRC.

The anti-Vibrio effects of RDRC could be due to the combined mode of action of different plant extracts present in the pill. Methyl gallate, one of the active ingredients of $T$. chebula Retz., a major component of RDRC has been found to act as an effective agent for the treatment of severe secretory and inflammatory diarrheal diseases caused by multidrug-resistant strains of $V$. cholerae (29). A high level of antibacterial activity was reported for $V$. parahaemolyticus by the use of extracts of Phytolacca americana Linn. (30). Myrtiscin and Eugenol found in Myristica fragrans Houtt., another predominant constituent of RDRC, have been shown to have excellent antibacterial action against $V$. cholerae (31). Our preliminary antibacterial studies for the three highly pathogenic Vibrio species have depicted the potential antagonistic action of the extract of the Tibetan precious pill RDRC against these bacteria causing life-threatening infections.

\section{Conclusion}

The current study was successful in validating the antibacterial effect of the chloroform extract of the Tibetan Precious Pill, Rinchen Drangjor Rilnag Chenmo (RDRC), against three highly infectious and virulent Vibrio species. Further studies are being planned to investigate the molecular mechanism of disruption of bacterial growth. This will definitely be useful in proving the projected success of such pills in treating a multitude of diseases ailing humankind. Globally, different ethnic groups have evolved their own traditional medical practices, some of which have really been shown to be efficient in curing dreaded diseases. With the advancements made in biochemistry and molecular biology, more scientific validation of the medicinal effects of such traditional pills is indeed the need of the hour.

\section{Acknowledgements}

The authors would like to thank the Department of Life Sciences, CHRIST (Deemed to be University), Bangalore, for the infrastructural facilities provided for the study. Special thanks to Men-Tsee-Khang (Tibetan Medical and Astro-science Institute), Himachal Pradesh, India, for granting permission to work on the precious pill.

\section{Authors' contributions}

SS proposed the study. Sample collection and performance of experiments were done by SD. IP and SB helped in the manuscript preparation; all authors read and approved the final manuscript.

\section{Conflict of interests}

Authors do not have any conflict of interests to declare.

\section{References}

1. Dakpa T. Unique aspect of Tibetan medicine. Acupuncture and Electro-therapeutics Research. 2014 Mar 1;39(1):27-43. https://doi.org/10.3727/036012914X13966138791145

2. Loizzo JJ, Blackhall LJ, Rapgay L. Tibetan medicine. Annals of the New York Academy of Sciences. 2009 Aug 1;1172(1):218. https://doi.org/10.1196/annals.1393.008

3. Luo H, Zhong G, Yue L, Wang Q, Ma L, Luobu Z. Traditional Tibetan medicine in China: A systematic overview of randomized clinical trials. European Journal of Integrative $\begin{array}{llll}\text { Medicine. } & 2015 & \text { Oct } & 1 ; 7(5): 450-59 .\end{array}$ https://doi.org/10.1016/j.eujim.2015.05.001

4. Kloos S. The recognition of Sowa Rigpa in India. Medicine Anthropology Theory. $2016 \quad$ Sep 13;3(2):19-49. https://doi.org/10.17157/mat.3.2.351

5. Bauer-Wu S, Lhundup T, Tidwell T, Lhadon T, Ozawa-de Silva C, Dolma J, Dorjee P, Neshar DR, Sangmo R, Yeshi T. Tibetan medicine for cancer: An overview and review of case studies. Integrative Cancer Therapies. 2014 Nov 13(6):502-12. https://doi.org/10.1177/1534735414549624

6. Rinchen Drangjor Rilnag Chenmo. Tibetan Medical and Astroscience Institute [Website][cited 2021 May 10]. Available from: https://men-tsee-khang.org/medicine/rinchen-pills/drangjor.htm

7. Gerke B. The social life of tsotel: processing mercury in contemporary Tibetan medicine. Asian Medicine. 2013 Sep 17;8(1):120-52. https://doi.org/10.1163/15734218-12341287

8. Collins D. Book Review: Manufacturing Tibetan Medicine: The Creation of an Industry and the Moral Economy of Tibetanness. International Journal of Asian Studies. 2015;12(1):120. https://doi.org/10.1017/S1479591414000308

9. De Castro ML, Garcia-Ayuso LE. Soxhlet extraction of solid materials: an outdated technique with a promising innovative future. Analytica Chimica Acta. 1998 Aug 10;369(1-2):1-10. https://doi.org/10.1016/S0003-2670(98)00233-5

10. Jaradat N, Hussen F, Al Ali A. Preliminary phytochemical screening, quantitative estimation of total flavonoids, total phenols and antioxidant activity of Ephedra alata Decne. J Mater Environ Sci. 2015;6(6):1771-78.

11. Naeem I, Saddiqe Z, Patel AV, Hellio C. Flavonoid analysis and antibacterial activity of extracts of Hypericum perforatum. Asian J Chem. 2010;22:3596-600.

12. Magaldi S, Mata-Essayag S, De Capriles CH, Perez C, Colella MT, Olaizola C, Ontiveros Y. Well diffusion for antifungal susceptibility testing. International Journal of Infectious Diseases. $\quad 2004 \quad$ Jan 1;8(1):39-45 https://doi.org/10.1016/j.ijid.2003.03.002

13. Nakaguchi Y. Contamination with Vibrio parahaemolyticus and its virulent strains in seafood marketed in Thailand, Vietnam, Malaysia and Indonesia from 2008 to 2011. Tropical Medicine and Health. 2013:2011-06. https://doi.org/10.2149/tmh.2011-06 
14. Letchumanan, V., Yin, W. F., Lee, L. H., Chan, K. G. Prevalence and antimicrobial susceptibility of Vibrio parahaemolyticus isolated from retail shrimps in Malaysia. Front Microbiol. 2015;6:33. https://doi.org/10.3389/fmicb.2015.00033

15. Bonnin-Jusserand M, Copin S, Le Bris C, Brauge T, Gay M, Brisabois A, Grard T, Midelet-Bourdin G. Vibrio species involved in seafood-borne outbreaks (Vibrio cholerae, $V$. parahaemolyticus and $V$. vulnificus): review of microbiological versus recent molecular detection methods in seafood products. Critical Reviews in Food science and Nutrition. 2019 Feb https://doi.org/10.1080/10408398.2017.1384715

$21 ; 59(4): 597-610$

16. Scallan E, Hoekstra RM, Angulo FJ, Tauxe RV, Widdowson MA, Roy SL, Jones JL, Griffin PM. Foodborne illness acquired in the United States-major pathogens. Emerging Infectious Diseases. 2011 Jan;17(1):7. https://doi.org/10.3201/eid1701.P11101

17. Nair GB, Ramamurthy T, Bhattacharya SK, Dutta B, Takeda Y, Sack DA. Global dissemination of Vibrio parahaemolyticus serotype 03: K6 and its serovariants. Clinical Microbiology Reviews. 2007 Jan 1;20(1):39-48. https://doi.org/10.1128/CMR.00025-06

18. Silva YJ, Costa L, Pereira C, Mateus C, Cunha A, Calado R, Gomes NC, Pardo MA, Hernandez I, Almeida A. Phage therapy as an approach to prevent Vibrio anguillarum infections in fish larvae production. PLoS One. 2014 Dec 2;9(12):114197. https://doi.org/10.1371/journal.pone.0114197

19. Chandrakala N, Ganesh PS, Prabakaran M, Thangamathi P, Aruljothi R, Bharathidasan R. Comparative study on the antiVibrio activity of vibrio species isolated from Penaeus monodon, sillago sihama against spices. Indian Journal of GeoMarine Sciences. 2013 Nov 42(7):934-36.

20. Todd EC. Preliminary estimates of costs of foodborne disease in the United States. Journal of Food Protection. 1989 Aug;52(8):595-601. https://doi.org/10.4315/0362-028X-52.8.595

21. Kramer JM, Gilbert RJ, Doyle MP. Foodborne Bacterial Pathogens. by MP Doyle, Marcel Dekker, Inc., New York and Basel. 1989:22-70.

22. Jackson JK, Murphree RL, Tamplin ML. Evidence that mortality from Vibrio vulnificus infection results from single strains among heterogeneous populations in shellfish. Journal of Clinical Microbiology. 1997 Aug 1;35(8):2098-01. https://doi.org/ 10.1128/jcm.35.8.2098-2101.1997

23. Igbinosa EO, Idemudia OG. Anti-vibrio potentials of acetone and aqueous leaf extracts of Ocimum gratissimum Linn. Tropical Journal of Pharmaceutical Research. 2016;15(4):74350. https://doi.org/10.4314/tjpr.v15i4.11

24. Nealson KH, Hastings JW. Quorum sensing on a global scale: massive numbers of bioluminescent bacteria make milky seas. Applied and Environmental Microbiology. $2006 \mathrm{Apr}$ 1;72(4):2295-97. https://doi.org/10.1128/AEM.72.4.22952297.2006

25. Vezzulli L, Previati M, Pruzzo C, Marchese A, Bourne DG, Cerrano C, Vibrio Sea Consortium. Vibrio infections triggering mass mortality events in a warming Mediterranean Sea.
Environmental Microbiology. $2010 \quad$ Jul;12(7):2007-19. https://doi.org/10.1111/j.1462-2920.2010.02209.x

26. Pavia AT, Bryan JA, Maher KL, Hester Jr TR, Farmer III JJ. Vibrio carchariae infection after a shark bite. Annals of Internal Medicine. 1989 Jul 1;111(1):85-86. https://doi.org/10.7326/0003-4819-111-1-85

27. Vaseeharan B, Ramasamy P, Chen JC. Antibacterial activity of silver nanoparticles (AgNps) synthesized by tea leaf extracts against pathogenic Vibrio harveyi and its protective efficacy on juvenile Fenneropenaeus indicus. Letters in Applied Microbiology. $2010 \quad$ Apr;50(4):352-56. https://doi.org/10.1111/j.1472-765X.2010.02799.x

28. Bahabadi MN, Delavar FH, Mirbakhsh M, Niknam K, Johari SA. Assessment of antibacterial activity of two different sizes of colloidal silver nanoparticles (cAgNPs) against Vibrio harveyi isolated from shrimp Litopenaeus vannamei. Aquaculture $\begin{array}{llll}\text { International. } & 2017 & \text { Feb } & 1 ; 25(1): 463-72 .\end{array}$ https://doi.org/10.1007/s10499-016-0043-8

29. Bag PK, Roy N, Acharyya S, Saha DR, Koley H, Sarkar P, Bhowmik P. In vivo fluid accumulation-inhibitory, anti colonization, anti-inflammatory and in vitro biofilm -inhibitory activities of methyl gallate isolated from Terminalia chebula against fluoroquinolones resistant Vibrio cholerae. Microb Pathog. $2019 \quad$ Mar $128: 41-46$ https://doi.org/10.1016/j.micpath.2018.12.037

30. Boo HO, Park JH, Woo SH, Park HY. Antimicrobial effect, antioxidant and tyrosinase inhibitory activity of the extract from different parts of Phytolacca americana L. 2015 Sep 30;60(3):366-73. https://doi.org/10.7740/kjcs.2015.60.3.366

31. $\mathrm{Nu}$ TT, Htun AA, Ngwe DH, Htay MM. Evaluation of antibacterial activity and isolation of some organic constituents from seeds of Myristica fragrans Houtt. (ZADEIK-PO). J Myanmar Acad Arts Sci. 2020 Jul;18:293-301.

\section{Additional information}

Peer review information: Plant Science Today thanks Sectional Editor and the other anonymous reviewers for their contribution to the peer review of this work.

Reprints and permissions information is available at https://horizonepublishing.com/journals/index.php/PST/open_access_policy

Publisher's Note: Horizon e-Publishing Group remains neutral with regard to jurisdictional claims in published maps and institutional affiliations.

To cite this article: Dhargyal S, Philip I, Biswas S, Sarojini S. Anti-vibrio effects of the precious Tibetan pill, Rinchen Drangjor Rilnag Chenmo (RDRC). Plant Science Today. 2021;8(3):681-687.

https://doi.org/10.14719/pst.2021.8.3.1225

Plant Science Today, published by Horizon e-Publishing Group, is covered by Scopus, Web of Science, BIOSIS Previews, Clarivate Analytics, etc. See https://horizonepublishing.com/journals/index.php/PST/indexing_abstracting 